\title{
Curcumin relieves mice gastric emptying dysfunction induced by $L$-arginine and atropine through interstitial cells of Cajal
}

\author{
PENG LIN $^{1 *}$, BAITAO LI $^{2 *}$, JUNLI YE $^{1}$, FANGFANG SHANG $^{3}$, HUI ZHAO $^{3}$, JING XIE $^{4}$ and XIAOLING YU ${ }^{1}$ \\ Departments of ${ }^{1}$ Physiology and Pathophysiology, and ${ }^{2}$ Biotechnology, School of Basic Medicine, Qingdao University, \\ Qingdao, Shandong 266021; ${ }^{3}$ Department of Pathology, Navy 971 Hospital of The People's Liberation Army, \\ Qingdao, Shandong 266000; ${ }^{4}$ Laboratory of Human Microscopic Structure, School of Basic Medicine, \\ Qingdao University, Qingdao, Shandong 266021, P.R. China
}

Received September 29, 2019; Accepted February 22, 2021

DOI: $10.3892 /$ etm.2021.9980

\begin{abstract}
Curcumin is natural polyphenol from Curcuma longa rhizomes with several biological properties. Our previous studies demonstrated that curcumin inhibited functional gastric emptying disorders induced by L-arginine, the precursor of nitric oxide (NO), and atropine, an acetylcholine receptor (AChR) blocker. However, the mechanism of action of curcumin remains unclear. In the present study, mouse models of functional gastric emptying disorders induced by L-arginine and atropine were used to examine changes in interstitial cells of Cajal (ICC) and NO- and ACh-mediated regulation of gastrointestinal motility. Curcumin pre-treatment ameliorated the gastric emptying rate in mice treated with $\mathrm{L}$-arginine or atropine $(\mathrm{P}<0.01)$. NO content and NO synthase activity significantly increased in the stomachs of L-arginine-treated mice, compared with controls $(\mathrm{P}<0.01)$. Acetylcholinesterase activity $(\mathrm{P}<0.01)$ and mRNA expression $(\mathrm{P}<0.01)$, as well as AChR mRNA levels $(\mathrm{P}<0.05)$ significantly decreased following atropine treatment. Moreover, in both models, the levels of c-kit, anoctamin 1 and connexin 43 significantly decreased in the stomach $(\mathrm{P}<0.01)$. Conversely, curcumin pre-treatment inhibited the changes induced by L-arginine and atropine $(\mathrm{P}<0.01$ or $\mathrm{P}<0.05)$. By affecting the production of exogenous NO, the effects of Ach-AchR and the biomarkers of ICC, curcumin relieves the gastric emptying dysfunction in mice.
\end{abstract}

\section{Introduction}

Curcumin is a phenolic pigment extracted from turmeric (Curcuma longa) rhizomes with anti-inflammatory,

Correspondence to: Dr Xiaoling Yu, Department of Physiology and Pathophysiology, School of Basic Medicine, Qingdao University, 308 Ningxia Road, Qingdao, Shandong 266021, P.R. China

E-mail: xiaoling_yu2004@163.com

*Contributed equally

Key words: acetylcholine, atropine, curcumin, functional gastrointestinal disorders, nitric oxide antioxidant and anti-cancer properties (1-5). In the gastrointestinal tract, curcumin plays important anti-inflammatory and tumor-suppressive roles (6-8). Our previous study suggested that gastrointestinal food propulsion was delayed by exogenous nitric oxide (NO) and atropine in mice and that curcumin could attenuate this effect (9). However, the mechanism of action of curcumin remains unclear.

NO synthase (NOS) generates NO using L-arginine as a precursor in vivo. NO is non-cholinergic and non-adrenergic neurotransmitter that inhibits gastrointestinal motility by relaxing gastrointestinal smooth muscles (10). Atropine is an antagonist of acetylcholine receptors (AChRs) that inhibits the contracting effect of $\mathrm{ACh}$ on gastrointestinal smooth muscles (11). Moreover, NO also can inhibit gastrointestinal motility by disrupting the activity of ICC (12) and ACh can stimulate ICC to regulate gastrointestinal motility by combining with the corresponding neurotransmitter receptor (13). ICC are mesenchymal cells that serve a key role in normal gastrointestinal motility $(14,15)$. ICC mediate the interaction between the autonomic nervous system and smooth muscle cells of the digestive tract. Thus, ICC act as the 'pacemaker' of the gastrointestinal tract by generating spontaneous electrical slow waves and regulating rhythmic peristalsis (16). A previous study reported that ICC depletion and damage, network disruption $(17,18)$ and the decreased expression of calcium-activated chloride channel (19) may lead to aberrant slow wave initiation and conduction. The c-kit tyrosine kinase receptor is an established marker of ICC (20). Indeed, c-kit and its ligand, stem cell factor (SCF), regulate ICC proliferation, development and functional maintenance (21). Insufficient c-kit/SCF signaling contributes to intestinal motility dysfunction induced by hypoxia in neonatal mice (22). Anoctamin 1 (Ano1) is a calcium-activated chloride channel identified as a selective molecular marker ICC in the human and murine gastrointestinal tracts (23). Slow gastrointestinal contraction depends on Anol activation in ICC (24). In addition, the gap junction protein connexin 43 (CX43) also serves a key role in the transmission and regulation of gastrointestinal motility $(25,26)$.

The aim of the present study was to determine the mechanisms through which curcumin improves gastrointestinal motility using L-arginine and atropine-induced murine 
models of functional gastric emptying disorder. In addition to $\mathrm{NO}$ and $\mathrm{ACh}$ levels, the expression levels of several ICC markers, including C-kit, Ano1 and CX43, were also examined in the stomach to determine whether curcumin alters ICC.

\section{Materials and methods}

Chemicals. Curcumin (Sigma-Aldrich; Merck KGaA) was mixed in a $5 \%$ gum arabic solution to a concentration of $25 \mathrm{~g} / 1$ for intragastric administration. L-arginine (Sigma-Aldrich; Merck KGaA) was mixed with a 5\% gum arabic suspension for a final concentration of $250 \mathrm{~g} / \mathrm{l}$. Atropine Sulfate Injection (Tianjin Pharmaceutical Group Xinzheng Co., Ltd.) was diluted with saline to a concentration of $0.075 \mathrm{~g} / \mathrm{l}$.

Animals. Because hormone secretion in female mice may affect experimental results, male mice were exclusively used in the present study. A total of 40 male Kunming mice (3 weeks) weighing 19-22 $\mathrm{g}$ were supplied by Jinan Pengyue Experimental Animal Co. Ltd. The mice were housed at $18-22^{\circ} \mathrm{C}$ and $50-60 \%$ humidity, in a 12-h light/dark cycle with free access to food and water. They were allowed to acclimatize to their surroundings for a week before experimentation. All animal experiments were approved by The Animal Ethics Committee of Qingdao University (approval no. QYFY WZLL 2017-10-16).

L-arginine-induced model establishment. Mice were randomly divided into normal (untreated) control, curcumin, $\mathrm{L}$-arginine and curcumin $+\mathrm{L}$-arginine groups $(\mathrm{n}=10$ mice/group). Curcumin $(200 \mathrm{mg} / \mathrm{kg}$ ) was administered intragastrically in a $0.2-\mathrm{ml}$ volume once per day for 15 days, as previously described (9). Mice in the curcumin-untreated groups received gum arabic suspension alone. From the $11^{\text {th }}$ day, $2 \mathrm{~g} / \mathrm{kg} \mathrm{L}$-arginine $(2 \mathrm{~g} / \mathrm{kg}, 0.2 \mathrm{ml})$ suspension was administered intragastrically in a $0.2-\mathrm{ml}$ volume once per day for 5 consecutive days. Mice in L-arginine-untreated groups received gum arabic suspension.

Atropine-induced model establishment. Similar to the L-arginine model, mice were randomly divided into normal control, curcumin, atropine and curcumin + atropine groups ( $\mathrm{n}=10$ mice/group). Curcumin was administered as described for the L-arginine-induced model. On the $16^{\text {th }}$ day, $0.5 \mathrm{mg} / \mathrm{kg}$ atropine sulfate was injected intraperitoneally in a $0.2-\mathrm{ml}$ volume. Mice in atropine-untreated groups received $0.2 \mathrm{ml}$ physiological saline.

Gastric emptying rate. All mice were fasted for $24 \mathrm{~h}$. A volume of $0.8 \mathrm{ml}$ semi-fluid gum arabic solution was administered intragastrically to mice for gastric emptying test. The animals were sacrificed by cervical dislocation 20 min later. The stomach was removed and weighed to determine the total weight (T), then cut along the greater curvature to remove the contents. The stomach was then weighed again to obtain the net weight (t). The gastric emptying rate (\%) was calculated according to the following formula $[1-(\mathrm{X} / \mathrm{Y})] \mathrm{x} 100$, where $\mathrm{X}=\mathrm{T}-\mathrm{t}$, and $\mathrm{Y}$ is volume of semi-fluid solution.

NO content, acetylcholinesterase (AChE) and NOS activity measurement. Total of $4 \mathrm{~g}$ of gastric tissue were ground into a $10 \%$ homogenate solution at $4^{\circ} \mathrm{C}$ in lysis buffer according to the manufacturer's instructions (NO assay kit, cat. no. A102-1; AchE assay kit, cat. no. A024-1-1; NOS typed assay kit, cat. no. A014-1; all from Nanjing Jiancheng Bioengineering Institute). After a $10-$ min centrifugation at $2,500-3,500 \mathrm{x} \mathrm{g}$ and $4^{\circ} \mathrm{C}$, the supernatant was collected and combined with the color development reaction solution from the aforementioned kits. The samples were then transferred to a 96-well plate and absorbance was measured with an automatic enzyme marker to calculate NO content $(550 \mathrm{~nm})$ and the activities of NOS $(530 \mathrm{~nm})$ and $\mathrm{AChE}(412 \mathrm{~nm})$.

Reverse transcription-quantitative PCR (RT-qPCR). RT-qPCR was carried out to measure the expression of the AChE, AChR, c-kit, CX43 and Ano1 genes. Total RNA was extracted from mouse gastric tissue using TRIzol ${ }^{\circledR}$ (Invitrogen; Thermo Fisher Scientific, Inc.). A total of $1 \mu \mathrm{g}$ RNA was reverse transcribed at $37^{\circ} \mathrm{C}$ for $15 \mathrm{~min}$ and $85^{\circ} \mathrm{C}$ for $5 \mathrm{sec}$, using the PrimeScript RT reagent kit (Takara Bio, Inc.). qPCRs were carried out using SYBR Premix Ex Taq II (Takara Bio, Inc.) on a 7500 Fast Sequence Detection System (Applied Biosystems; Thermo Fisher Scientific, Inc.). The thermocycling conditions were as follows: Initial denaturation at $95^{\circ} \mathrm{C}$ for $30 \mathrm{sec}$; followed by 40 cycles at $95^{\circ} \mathrm{C}$ for $10 \mathrm{sec}, 60^{\circ} \mathrm{C}$ for $20 \mathrm{sec}$ and $72^{\circ} \mathrm{C}$ for $30 \mathrm{sec}$. All reactions were set up in triplicate for each sample. Primers were purchased from Sangon Biotech Co., Ltd. (Table I). The expression levels of mRNA were calculated using the $2^{-\Delta \Delta C q}$ method (27). Gene expression was normalized to a GAPDH internal control, and data are presented as $\mathrm{n}$-fold expression difference of each sample relative to the respective control group.

Western blotting. Proteins were extracted from stomach tissue by homogenization at $4^{\circ} \mathrm{C}$ in RIPA lysis buffer supplemented with phenylmethylsulphonyl fluoride (Beijing Solarbio Science \& Technology Co., Ltd.). The lysate was centrifuged at $10,000 \mathrm{x} \mathrm{g}$ and $4^{\circ} \mathrm{C}$ for $5 \mathrm{~min}$, and protein concentration in the supernatant was quantified using a bicinchoninic acid assay kit (Beyotime Institute of Biotechnology). Protein samples $(15 \mu \mathrm{g})$ were loaded into each lane of a 5\% stacking gel and 8\% resolving gel (Beijing Solarbio Science \& Technology Co., Ltd.) and separated by SDS-PAGE. Proteins were electrotransferred to PVDF membranes. The membranes were then blocked in 5\% milk for $1 \mathrm{~h}$ at room temperature, then incubated at $37^{\circ} \mathrm{C}$ for $1 \mathrm{~h}$ with the following primary antibodies against the following proteins purchased from BIOSS: i) CX43 (1:500), cat. no. bs-0651R; ii) c-kit (1:500), cat. no. bs-0672R; iii) ano1 (1:300), cat. no. bs-9061R; and iv) GAPDH (1:500), cat. no. bs-0755R. After three washes with $1 \mathrm{X}$ TBS $+0.1 \%$ Tween-20, the membranes were incubated with horseradish peroxidase-conjugated secondary antibody (goat anti-rabbit IgG (H+L)/HRP antibody (1:3,000), cat. no. bs-40295G-HRP; Beijing Biosynthesis Biotechnology Co., Ltd.) for $1 \mathrm{~h}$ at room temperature. Protein bands were visualized with ECL Western Blotting Substrate (Thermo Fisher Scientific, Inc.). Densitometry was carried out using ImageJ software (version no. 1.52; National Institutes of Health).

Statistical analysis. All assays in the present study were repeated three times. Data analysis was performed using 

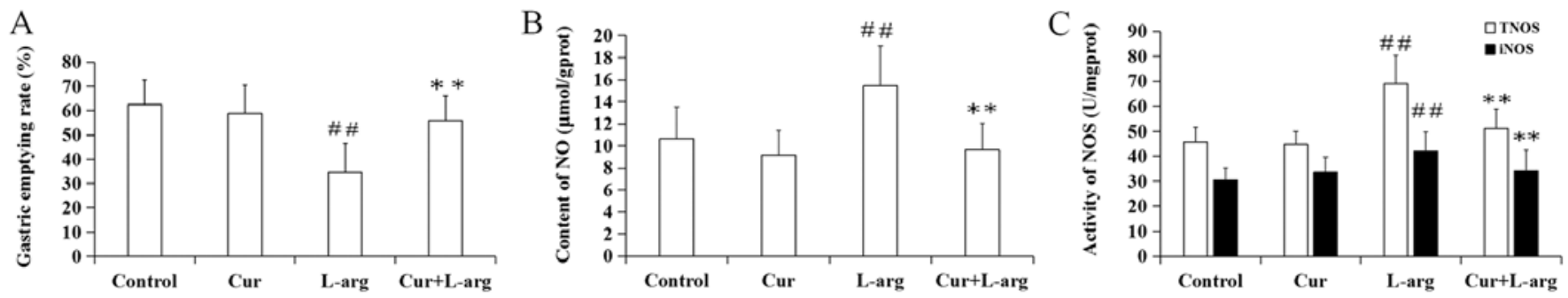

Figure 1. Changes in gastric emptying rates and the relative biomarkers of NO following Cur and L-arg treatment. (A) Changes in gastric emptying rates. (B) NO content. (C) TNOS and (C) iNOS activity. Data are presented as the mean \pm SD; ${ }^{* \#} \mathrm{P}<0.01$ vs. Control; ${ }^{* *} \mathrm{P}<0.01$ vs. L-arg. Cur, curcumin; gprot, grams of protein; iNOS, inducible NO synthase; L-arg, L-arginine; mgprot, milligrams of protein; NO, nitric oxide; TNOS, total NO synthase.

Table I. Primer sequences used for reverse transcription-quantitative PCR.

\begin{tabular}{ll}
\hline Gene & \multicolumn{1}{c}{ Primer sequence $\left(5^{\prime} \rightarrow 3^{\prime}\right)$} \\
\hline AchE & F: ACCTGCTTCTCCCACACCT \\
& R: GGTTCCACTCGGTAGTTCA \\
AchR & D: CATCTTGCTGGCTTTCATCA \\
& R: CACAGCCAGTAGCCCAGATT \\
C-kit & F: AGCGTGTGTAAATCGTGTTTG \\
& R: ACATTCAGCATTCCTCCCATA \\
Ano1 & F: AGCGGAAGCAGCGCTATGA \\
& R: GGGTGACAAAGCCGAACTGAA \\
CX43 & F: ACCCAACAGCAGCAGACTTTGA \\
& R: GCTTGGACCTTGTCCAGCAG \\
GAPDH & F: CGGAGTCAACGGATTTGGTCGTAT \\
& R: AGCCTTCTCCATGGTGGTGAAGAC
\end{tabular}

Ano1, anoctamin 1; AChE, acetylcholinesterase; AChR, acetylcholine receptor; CX43, connexin 43.

SPSS 17.0 (SPSS, Inc.). Data are expressed as the mean \pm SD. Multigroup comparisons were analyzed using ANOVA, followed by Tukey's post hoc test. $\mathrm{P}<0.05$ was considered to indicate a statistically significant difference.

\section{Results}

Changes in gastric emptying rate in the L-arginine model. Following L-arginine treatment, the gastric emptying rate significantly decreased, compared with the control $(\mathrm{P}<0.01$; Fig. 1A). However, curcumin pre-treatment significantly improved the delayed gastric emptying rate caused by $\mathrm{L}$-arginine $(\mathrm{P}<0.01)$. In addition, the administration of curcumin alone had no significant effect on the gastric emptying rate, compared with control mice $(\mathrm{P}>0.05)$.

Changes in NO content, total NOS (TNOS) and inducible NOS (iNOS) activity in the L-arginine model. L-arginine administration significantly increased NO content, as well as TNOS and iNOS activities compared with the control group $(\mathrm{P}<0.01)$. However, pretreatment with curcumin led to a decrease in all three parameters compared with L-arginine-treated mice

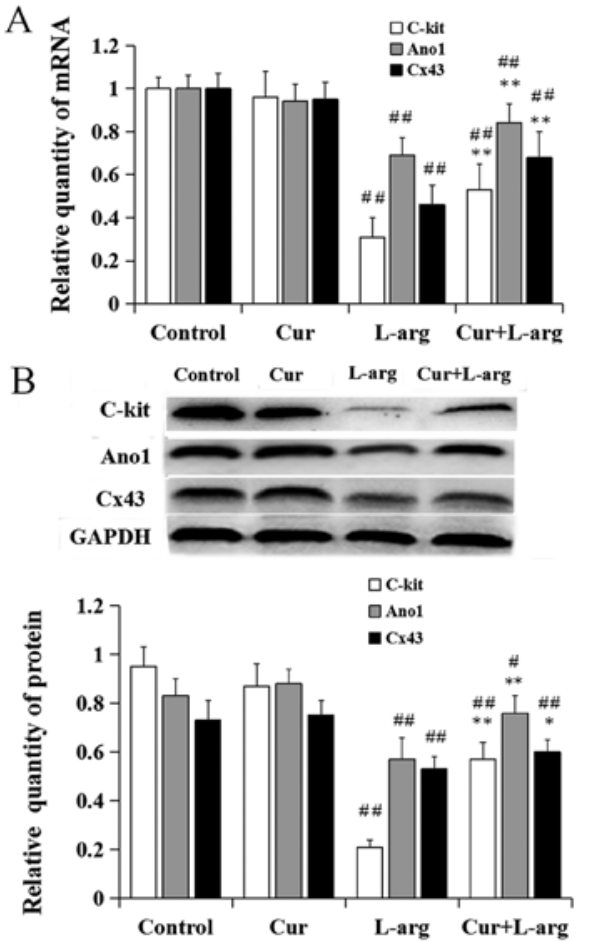

Figure 2. Changes in relative expression levels interstitial cells of Cajal markers following Cur and L-arg treatment. (A) Reverse transcription-quantitative PCR and (B) Western blot analysis. Data are presented as the mean $\pm \mathrm{SD} ;{ }^{\#} \mathrm{P}<0.05$ and ${ }^{\# \#} \mathrm{P}<0.01$, vs. Control; ${ }^{*} \mathrm{P}<0.05$ and ${ }^{* *} \mathrm{P}<0.01$ vs. L-arg. Ano1, anoctamin 1; CX43, connexin 43; Cur, curcumin; L-arg, L-arginine.

$(\mathrm{P}<0.01)$. Moreover, curcumin alone had no significant effect on NO content, TNOS activity and iNOS activity compared with control mice ( $\mathrm{P}>0.05$, respectively; Fig. $1 \mathrm{~B}$ and $\mathrm{C}$ ).

Changes in the expression of ICC markers in the L-arginine model. Following the administration of L-arginine, the relative mRNA levels of c-kit, anol and CX43 significantly decreased compared with control $(\mathrm{P}<0.01)$. Pretreatment with curcumin increased c-kit, ano1 and CX43 mRNA expression compared with L-arginine alone $(\mathrm{P}<0.01)$. There was no difference in gene expression of these markers following treatment with curcumin alone compared with controls $(\mathrm{P}>0.05$, respectively; Fig. 2A). Similar results for protein expression levels were demonstrated by western blot analysis (Fig. 2B).

Changes in gastric emptying rates in the atropine model. The gastric emptying rate significantly decreased following 

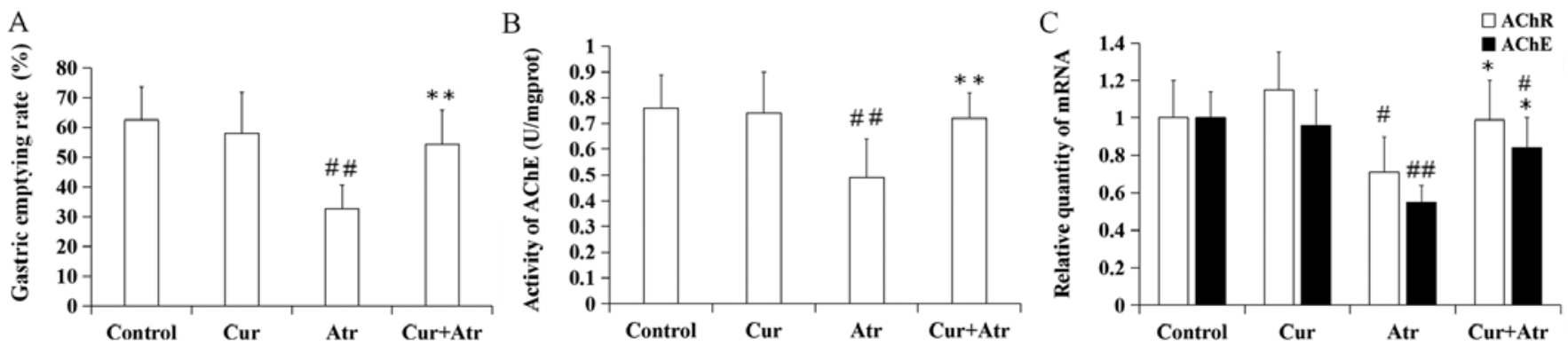

Figure 3. Changes in gastric emptying rates and the relative biomarkers of ACh following Cur and Atr treatment. (A) Changes in gastric emptying rates. (B) Activity levels of AChE. (C) AChE and AChR mRNA expression levels. Data are presented as the mean $\pm \mathrm{SD}$; ${ }^{*} \mathrm{P}<0.05$ and ${ }^{\# \#} \mathrm{P}<0.01 \mathrm{vs}$. Control; ${ }^{*} \mathrm{P}<0.05$ and ${ }^{* *} \mathrm{P}<0.01$ vs. Atr. AChE, acetylcholinesterase; AChR, acetylcholine receptor; Atr, atropine; Cur, curcumin; mgprot, milligrams of protein.
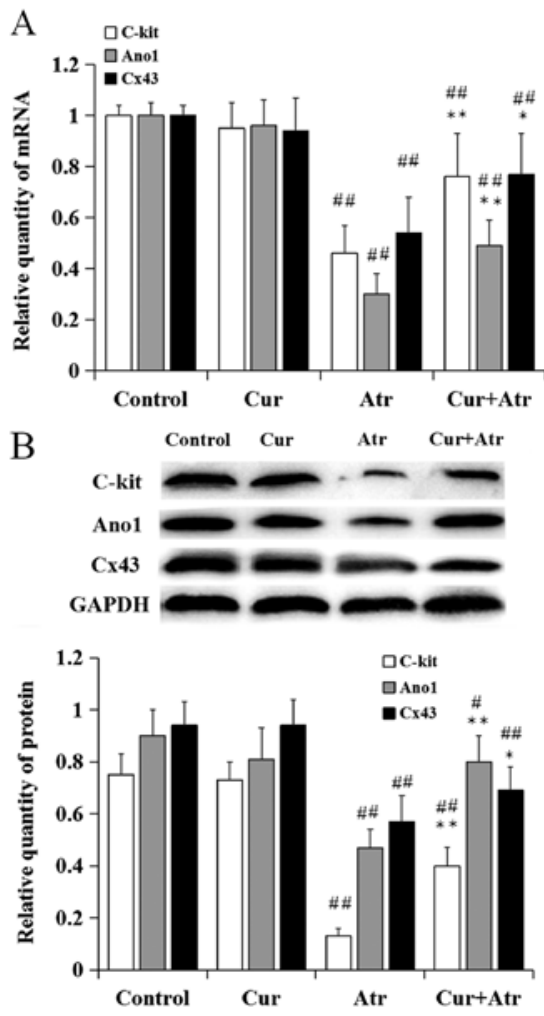

Figure 4. Changes in relative expression levels of interstitial cells of Cajal markers following Cur and Atr treatment. (A) Reverse transcription-quantitative PCR and (B) Western blot analysis. Data are presented as the mean $\pm \mathrm{SD}$; ${ }^{\#} \mathrm{P}<0.05$ and ${ }^{\# \#} \mathrm{P}<0.01$, vs. Control; ${ }^{*} \mathrm{P}<0.05$ and ${ }^{* *} \mathrm{P}<0.01$ vs. Atr. Anol, anoctamin 1; atr, atropine; Cur, curcumin; CX43, connexin 43.

atropine treatment compared with the control group $(\mathrm{P}<0.01)$. However, curcumin pre-treatment significantly improved the delayed gastric emptying rate induced by atropine $(\mathrm{P}<0.01)$. Curcumin alone had no significant effect compared with control mice ( $\mathrm{P}>0.05$; Fig. 3A).

Changes in AChE and AChR levels in the atropine model. Following the administration of atropine, the activity of AChE $(\mathrm{P}<0.01)$, and the relative mRNA expression levels of AChE $(\mathrm{P}<0.01)$ and AChR $(\mathrm{P}<0.05)$ significantly decreased compared with the control group. Pretreatment with curcumin increased AChE activity $(\mathrm{P}<0.01)$ and mRNA expression of $\mathrm{AChE}(\mathrm{P}<0.05)$ and $\mathrm{AChR}(\mathrm{P}<0.05)$ compared with atropine alone. Curcumin alone had no significant effect on AChE activity $(\mathrm{P}>0.05)$ and gene expression of $\mathrm{AChE}(\mathrm{P}>0.05)$ and $\mathrm{AChR}(\mathrm{P}>0.05)$ (Fig. 3B and C, respectively).

Changes in the expression of ICC markers in the atropine model. Following atropine treatment, the relative mRNA levels of c-kit, ano1 and CX43 significantly decreased, compared with control $(\mathrm{P}<0.01)$. However, curcumin pre-treatment significantly increased the mRNA levels of $\mathrm{c}$-kit $(\mathrm{P}<0.01)$, ano1 $(\mathrm{P}<0.01)$ and CX43 $(\mathrm{P}<0.05)$ compared with atropine alone. Curcumin alone had no significant effect on the expression of ICC markers compared with control mice ( $\mathrm{P}>0.05$; Fig. 4A). Similar results of the protein expression levels were demonstrated by western blot analysis (Fig. 4B).

\section{Discussion}

NO acts as an inhibitory neurotransmitter that relaxes gastrointestinal smooth muscles. However, excessive NO production can induce gastrointestinal motility dysfunction (10). Previous studies have reported that curcumin can inhibit iNOS activity, thereby reducing NO production in an in vitro model of inflamed human intestinal mucosa $(28,29)$. In the present study, pretreatment with curcumin improved the gastric emptying rate in vivo using a murine model of gastric emptying disorders. In the L-arginine-induced model, curcumin pre-treatments decreased $\mathrm{NO}$ content and inhibited iNOS activity. It has been reported that curcumin promotes the degradation of iNOS and suppresses its enzyme activities in various types of cells $(30,31)$. However, to the best of our knowledge, there are no previous reports about curcumin improving gastrointestinal dysfunction by inhibiting the activity of iNOS. The present findings provide additional evidence that curcumin ameliorates functional gastrointestinal dysfunction through the inhibition of iNOS activity.

$\mathrm{ACh}$ is a neurotransmitter that can induce contraction of gastrointestinal smooth muscles by binding to the AChR. Once released into the synapse, $\mathrm{ACh}$ is rapidly hydrolyzed by $\mathrm{AChE}$ to choline and acetic acid (32), and AChE activity can be measured by detecting the amount of choline in tissues. A previous study suggested that ACh release could increase AChE mRNA levels (33). Thus, the activity and mRNA level of AChE can reflect the release of ACh. In the atropine-induced mouse model of gastric emptying disorders, curcumin pre-treatment led to an increase in the activity and mRNA levels of AChE, suggesting that curcumin improved gastric emptying rate by stimulating 
ACh release in gastric tissues. This was also confirmed by the increased expression of AChR mRNA. The findings of the present study are in agreement with previous studies carried out in animal models. For example, curcumin increases AChE activity in the mice brain (34). Moreover, curcumin promoted $\mathrm{ACh}$ release in rat brain tissue (35). Nevertheless, how curcumin promotes ACh release is not fully understood.

Gastrointestinal motility is regulated by NO-mediated inhibition (12) and ACh-mediated stimulation (13) of ICC. In the present study, changes in the expression levels of ICC markers were also evaluated in murine gastric tissue. In both the L-arginine and atropine models, c-kit, ano1 and CX43 mRNA levels significantly decreased. However, pretreatment with curcumin inhibited the downregulation of these markers, suggesting that functional gastric emptying disorders caused by L-arginine and atropine may be related to ICC dysfunction. Thus, curcumin may alleviate functional gastric emptying disorders partly through an increase of related ICC signaling.

Through inhibiting exogenous NO production, promoting ACh release and improving signaling of ICC, curcumin may improve gastric emptying in the L-arginine and atropine mouse models, indicating that curcumin may promote delayed gastric emptying to some degree. Curcumin did not significantly affect the gastric emptying rate when administered alone. It is possible that a dose of $200 \mathrm{mg} / \mathrm{kg}$ curcumin intragastrically administered was not sufficient to affect the normal gastrointestinal tract. All indexes were observed $24 \mathrm{~h}$ after last application of curcumin. This time point fully ruled out the direct stimulation of curcumin in the stomach, which could more reasonably explain the effects of curcumin pre-treatment for more than 10 days. The dose and days of curcumin were chosen according to our previous study (9).

The use of curcumin has also been assessed in clinical trials, and early-phase trials have highlighted its safety and efficacy in patients (36). A previous study suggesting that high doses of curcumin were well-tolerated orally (37). However, the experimental biological benefits of curcumin have not yet been replicated in clinical trials, owing to its low bioavailability following oral administration (38). Nonetheless, since curcumin metabolites are detectable in the plasma following oral administration $(38,39)$, it is possible that the effects of curcumin are also mediated by its metabolites. In addition, several strategies have been employed to improve the solubility of curcumin $(40,41)$, which could improve its use and applicability.

In conclusion, the present study demonstrated that curcumin could reduce gastric emptying dysfunction. Thus, in addition to anti-inflammatory and antioxidant properties, curcumin could affect gastrointestinal peristalsis through inhibiting exogenous NO production, promoting ACh release and improving signaling of ICC. These findings identified a potential application for curcumin in the prevention of gastrointestinal disorders. However, the mechanism through which curcumin might exert its effect on gastric tissue, including ICC signal transduction, remains unclear. Owing to the complexity of regulation of gastrointestinal motility, other mechanisms of curcumin should be further examined.

\section{Acknowledgements}

Not applicable.

\section{Funding}

This work was supported by The Natural Science Foundation of Shandong Province (grant no. ZR2014HM033).

\section{Availability of data and materials}

The datasets used and/or analyzed during the current study are available from the corresponding author on reasonable request.

\section{Authors' contributions}

PL, BL and XY contributed to the experimental design, carried out experiments and wrote the manuscript. JY, FS, HZ and JX carried out experiments and data analysis. All authors agreed to be accountable for all aspects of the work in ensuring that questions related to the accuracy or integrity of any part of the work are appropriately investigated and resolved. All authors read and approved the final manuscript.

\section{Ethics approval and consent to participate}

The study was approved by the Ethics Committee of The Qingdao University (Qingdao, China; approval no. QYFY WZLL 2017-10-16).

\section{Patient consent for publication}

Not applicable.

\section{Competing interests}

The authors declare that they have no competing interests.

\section{References}

1. Bhawana, Basniwal RK, Buttar HS, Jain VK and Jain $\mathrm{N}$ : Curcumin nanoparticles: preparation, characterization, and antimicrobial study. J Agric Food Chem 59: 2056-2061, 2011.

2. Tsuda T: Curcumin as a functional food-derived factor: Degradation products, metabolites, bioactivity, and future perspectives. Food Funct 9: 705-714, 2018.

3. Daily JW, Yang M and Park S: Efficacy of turmeric extracts and curcumin for alleviating the symptoms of joint arthritis: A systematic review and meta-analysis of randomized clinical trials. J Med Food 19: 717-729, 2016.

4. Hussain Z, Thu HE, Amjad MW, Hussain F, Ahmed TA and Khan S: Exploring recent developments to improve antioxidant, anti-inflammatory and antimicrobial efficacy of curcumin: A review of new trends and future perspectives. Mater Sci Eng C 77: 1316-1326, 2017.

5. Yue GG, Kwok HF, Lee JK, Jiang L, Wong EC, Gao S, Wong HL, Li L, Chan KM, Leung PC, et al: Combined therapy using bevacizumab and turmeric ethanolic extract (with absorbable curcumin) exhibited beneficial efficacy in colon cancer mice. Pharmacol Res 111: 43-57, 2016.

6. Zhang X, Wu J, Ye B, Wang Q, Xie X and Shen H: Protective effect of curcumin on TNBS-induced intestinal inflammation is mediated through the JAK/STAT pathway. BMC Complement Altern Med 16: 299, 2016.

7. Murphy EA, Davis JM, McClellan JL, Gordon BT and Carmichael MD: Curcumin's effect on intestinal inflammation and tumorigenesis in the $\mathrm{Apc}^{\mathrm{Min} / \mathrm{+}}$ mouse. J Interferon Cytokine Res 31: 219-226, 2011.

8. Roberts JL, Poklepovic A and Booth L: Curcumin interacts with sildenafil to kill GI tumor cells via endoplasmic reticulum stress and reactive oxygen/ nitrogen species. Oncotarget 8: 99451-99469, 2017. 
9. Yu J, Xu WH, Sun W, Sun Y, Guo ZL and Yu XL: Curcumin alleviates the functional gastrointestinal disorders of mice in vivo. J Med Food 20: 1176-1183, 2017.

10. Garella R, Squecco R and Baccari MC: Site-related effects of relaxin in the gastrointestinal tract through nitric oxide signaling: An updated report. Curr Protein Pept Sci 18: 1254-1262, 2017.

11. Eglen RM: Muscarinic receptors and gastrointestinal tract smooth muscle function. Life Sci 68: 2573-2578, 2001.

12. Kaji N, Nakayama S, Horiguchi K, Iino S, Ozaki $H$ and Hori M: Disruption of the pacemaker activity of interstitial cells of Cajal via nitric oxide contributes to postoperative ileus. Neurogastroenterol Motil 30: 13334, 2018.

13. Sung TS, Hwang SJ, Koh SD, Bayguinov Y, Peri LE, Blair PJ, Webb TI, Pardo DM, Rock JR, Sanders KM, et al: The cells and conductance mediating cholinergic neurotransmission in the murine proximal stomach. J Physiol 596: 1549-1574, 2018.

14. Al-Shboul OA: The importance of interstitial cells of cajal in the gastrointestinal tract. Saudi J Gastroenterol 19: 3-15, 2013.

15. Iino S, Ward SM and Sanders KM: Interstitial cells of Cajal are functionally innervated by excitatory motor neurones in the murine intestine. J Physiol 556: 521-530, 2004.

16. Rumessen JJ and Thuneberg L: Pacemaker cells in the gastrointestinal tract: Interstitial cells of Cajal. Scand J Gastroenterol Suppl 216: 82-94, 1996.

17. Chang IY, Glasgow NJ, Takayama I, Horiguchi K, Sanders KM and Ward SM: Loss of interstitial cells of Cajal and development of electrical dysfunction in murine small bowel obstruction. J Physiol 536: 555-568, 2001.

18. Wang TH, Angeli TR, Ishida S, Du P, Gharibans A, Paskaranandavadivel N, Imai Y, Miyagawa T, Abell TL, Farrugia G, et al: The influence of interstitial cells of Cajal loss and aging on slow wave conduction velocity in the human stomach. Physiol Rep 8: e14659, 2021.

19. Sanders KM: Spontaneous electrical activity and rhythmicity in gastrointestinal smooth muscles. Adv Exp Med Biol 1124: 3-46, 2019.

20. Tamada $\mathrm{H}$ and Kiyama $\mathrm{H}$ : Existence of c-Kit negative cells with ultrastructural features of interstitial cells of Cajal in the subserosal layer of the W/W(v) mutant mouse colon. J Smooth Muscle Res 51: 1-9, 2015

21. Tan YY, Ji ZL, Zhao G, Jiang JR, Wang D and Wang JM: Decreased SCF/c-kit signaling pathway contributes to loss of interstitial cells of Cajal in gallstone disease. Int J Clin Exp Med 7: 4099-4106, 2014

22. Ren H, Han J, Li Z and Xiong Z: Stem cell factor/kit signal insufficiency contributes to hypoxia-induced intestinal motility dysfunctions in neonatal mice. Dig Dis Sci 62: 1193-1203, 2017.

23. Gomez-Pinilla PJ, Gibbons SJ, Bardsley MR, Lorincz A, Pozo MJ, Pasricha PJ, Van de Rijn M, West RB, Sarr MG, Kendrick ML, et al: Anol is a selective marker of interstitial cells of Cajal in the human and mouse gastrointestinal tract. Am J Physiol Gastrointest Liver Physiol 296: G1370-G1381, 2009.

24. Drumm BT, Hennig GW, Battersby MJ, Cunningham EK, Sung TS, Ward SM, Sanders KM and Baker SA: Clustering of $\mathrm{Ca}^{2+}$ transients in interstitial cells of Cajal defines slow wave duration. J Gen Physiol 149: 703-725, 2017.

25. Nemeth L, Maddur S and Puri P: Immunolocalization of the gap junction protein Connexin43 in the interstitial cells of Cajal in the normal and Hirschsprung's disease bowel. J Pediatr Surg 35: 823-828, 2000

26. Zhang G, Xie S, Hu W, Liu Y, Liu M, Liu M and Chang X: Effects of electroacupuncture on interstitial cells of Cajal (ICC) ultrastructure and Connexin 43 protein expression in the gastrointestinal tract of functional dyspepsia (FD) rats. Med Sci Monit 22: 2021-2027, 2016.
27. Livak KJ and Schmittgen TD: Analysis of relative gene expression data using real-time quantitative PCR and the 2(-Delta Delta C(T)) Method. Methods 25: 402-408, 2001.

28. Somchit $M$, Changtam C, Kimseng R, Utaipan T, Lertcanawanichakul M, Suksamrarn A and Chunglok W: Demethoxycurcumin from Curcuma longa rhizome suppresses iNOS induction in an in vitro inflamed human intestinal mucosa model. Asian Pac J Cancer Prev 15: 1807-1810, 2014.

29. Dai C, Li B, Zhou Y, Li D, Zhang S, Li H, Xiao X and Tang S: Curcumin attenuates quinocetone induced apoptosis and inflammation via the opposite modulation of Nrf2/HO-1 and NF- $\kappa \mathrm{B}$ pathway in human hepatocyte L02 cells. Food Chem Toxicol 95: 52-63, 2016.

30. Ben P, Liu J, Lu C, Xu Y, Xin Y, Fu J, Huang H, Zhang Z, Gao Y, Luo L, et al: Curcumin promotes degradation of inducible nitric oxide synthase and suppresses its enzyme activity in RAW 264.7 cells. Int Immunopharmacol 11: 179-186, 2011.

31. Li M, Wang L, Liu H, Su B, Liu B, Lin W, Li Z and Chang L: Curcumin inhibits HeLa cell invasion and migration by decreasing inducible nitric oxide synthase. Nan Fang Yi Ke Da Xue Xue Bao 33: 1752-1756, 2013 (In Chinese).

32. Trang A and KhandharPB: Physiology, Acetylcholinesterase. StatPearls, 2020. https://www.ncbi.nlm.nih.gov/books/NBK539735/. Accessed July 10, 2020

33. Cresnar B, Crne-Finderle N, Breskvar K and Sketelj J: Neural regulation of muscle acetylcholinesterase is exerted on the level of its mRNA. J Neurosci Res 38: 294-299, 1994.

34. Abu-Taweel GM: Effects of curcumin on the social behavior, blood composition, reproductive hormones in plasma and brain acetylcholinesterase in cadmium intoxicated mice. Saudi J Biol Sci 23: 219-228, 2016.

35. Liu ZJ, Li ZH, Liu L, Tang WX, Wang Y, Dong MR and Xiao C: Curcumin attenuates beta-amyloid-induced neuroinflammation via activation of peroxisome proliferator-activated receptor-gamma function in a rat model of Alzheimer's disease. Front Pharmacol 7: 261, 2016.

36. Cruz-Correa M, Hylind LM, Marrero JH, Zahurak ML, Murray-Stewart T, Casero RA Jr, Montgomery EA, Iacobuzio-Donahue C, Brosens LA, Offerhaus GJ, et al: Efficacy and safety of curcumin in treatment of intestinal adenomas in patients with familial adenomatous polyposis. Gastroenterology 155: 668-673, 2018.

37. Sharma RA, McLelland HR, Hill KA, Ireson CR, Euden SA, Manson MM, Pirmohamed M, Marnett LJ, Gescher AJ and Steward WP: Pharmacodynamic and pharmacokinetic study of oral Curcuma extract in patients with colorectal cancer. Clin Cancer Res 7: 1894-1900, 2001

38. Wang L, Li W, Cheng D, Guo Y, Wu R, Yin R, Li S, Kuo HC, Hudlikar R, Yang H, et al: Pharmacokinetics and pharmacodynamics of three oral formulations of curcumin in rats. J Pharmacokinet Pharmacodyn 47: 131-144, 2020.

39. Lao CD, Ruffin MT IV, Normolle D, Heath DD, Murray SI, Bailey JM, Boggs ME, Crowell J, Rock CL and Brenner DE: Dose escalation of a curcuminoid formulation. BMC Complement Altern Med 6: 10, 2006

40. Kurniawansyah F, Quachie L, Mammucari R and Foster NR: Improving the dissolution properties of curcumin using dense gas antisolvent technology. Int J Pharm 521: 239-248, 2017.

41. Peng S, Li Z,Zou L, Liu W, Liu C and McClements DJ: Improving curcumin solubility and bioavailability by encapsulation in saponin-coated curcumin nanoparticles prepared using a simple pH-driven loading method. Food Funct 9: 1829-1839, 2018. 